\title{
Öğrenci Velilerinin Ilköğretim Din Kültürü ve Ahlak Bilgisi Derslerine Karşı Tutum Düzeylerinin Dini Tutum Düzeyleriyle Îlişkisi (Ön Araştırma)
}

\author{
NURULLAH ALTAS \\ DR, ANKARA Ü. ILAHIYAT FAKÜLTES \\ e-mail: atlas@divinity.ankara.edu.tr
}

\begin{abstract}
The Correlation of the Attitude Levels of Guardians of Students toward 'Primary Education Religious Culture and Ethics Course and Ethics Course' with the Religious Artitude Levels. Courses of religious culture and ethics' which have been instructed in Turkish Education since 1982 had been discussed from various directions. Nevertheless in these discussions attitude of guardians of students to these lectures and reasons of attitudes were not investigated sufficiently. The aim of the study is only to investigate the attitudes of guardians of primary school students towands religious education and to compare these attitudes with religious attitudes and traditional religious attitudes. In order to determinate countereffect between two attitudes, two different tools of measuring have been developed. Finally, the validity and reliability of these tools of has been tested on the samples.
\end{abstract}

key words

Religious Curture, Religious Education, Artitudes of Guardians of Students, Traditional, Tools of Measuring, Testing.

\section{A. Giriş}

İlköğretim okullannda 1982 yılında zorunlu dersler arasına alınan Din Kültürü ve Ahlak Bilgisi dersleri bu tarihten beri eğitim çevrelerinde tartışmalann odağında bulunmaktadır. Zorunluluğu, hukukiliği ve bilimsel dayanaklannın sorgulanmasının yanında okul çatısı altında yapılması ve yapılma yöntemleri din öğretimini, akademik alanda bir çok araştırma ve toplantının merkezine yerleştirmiştir. Yapılan bu toplantılarda, konu tartışlırken öğrenci velilerinin görüs ve değerlendirmeleri ile bu değerlendirmelerin hangi faktörlere bağh olarak farklllkk gösterdiği çok fazla ön plana alınmamıstır. Din eğitimi bilimcileri de içinde olmak üzere yurdumuzda sosyal bilimcilerin bu konu üzerinde söylediği sözlerin önemli bir bölümü kişisel gözlemlere dayalı olarak karşımı- 
za çıkmaktadır. Kişisel gözlemlere dayah yorumların ön plana çıkarılması, biraz da alandan elde edilen araştırmalara dayalı bilimsel birikimin yetersizliğinden kaynaklanmaktadır.

Alan araştırmalan elbette genel hakkında tam bir fikir veremez. Ancak, özellikle istatistiksel yöntemler işin içine girdiği zaman, bir olay veya olguyla bağlantılı faktörlerdeki farklilaşmalar konusunda önemli bulgular elde etme imkanımız bulunmaktadır. Elde edilen bu bulgulann ayn konuya ilişkin farkh araşturmalardan elde edilecek olanlarla desteklenmesi veya yanlışlanması veya zaman içindeki değişimlerin gözlenmesi alan araştırmalarındaki sistematikliğe ve sürekliliğge bağlıdır. Yaplan araştırmalara harcanan zaman ve ekonomik maliyetin boşa gitmemesi, bahsettiğim sistematiklik ve sürekliliğin sağlanması ile mümkün olacaktır.

Öğrenci velilerinin din öğretimi ve din kültürü öğretimine ilişkin tutumlanın ölçmek amacıyla başladığımız araştımanın ilk aşamasında tutumlan ölçebilecek bir ölçek geliştirerek Ankara ilindeki ilköğretim okullannda çocuklan okuyan veliler üzerinde bir ön uygulama gerçekleştirdik. Araşturmamızın daha sonraki aşamalannda ise geliştirilen bu ölçeği farklı illerde ve özellikle farkl kültürel yapıya sahip bölgelerde uygulayarak velilerin tutumlannın değişmesine sebep olan değişkenler belirlenecektir.

\section{Problem}

İlköğretim aşamasındaki Din Kültürü ve Ahlak Bilgisi dersleri 4-5-6-7 ve 8 . sınıflarda okutulmaktadır. Öğrenciler, yaklaşık 10 yaşından itibaren örgün eğitim bünyesinde din öğretimi ile karşılaşmaktadırlar. Bu yaşı din öğretimine başlamak için erken kabul edenler bulunmakla birlikte geç olduğunu düşünenler de bulunmaktadır'. Ancak, ülkemiz şartlannda düşünüldüğünde bizce öğrencinin din öğretimi ile tanışması oldukş̧a geç bir dönemde gerçekleşmektedir. Çünkü öğrenci, daha okula başlamadan önce 'çevresinde dini kavramlarla karşlaşmakta, ailesinin sosyal özelliklerine göre bir takım dini törenlere katılmakta hatta informal düzeyde bile olsa din eğitimi almaya başlamaktadır. Beyza Bilgin, din öğretimi ne zaman başlamalı sorusunu cevaplarken, bireyin dinle ilgili sorularının başlamasım başlangı̨ noktası olarak belirlemektedir². Gerçekten de yetişmekte olan birey, dinle ilgili soruların okul içindeki derslerin de yardımı ile cevaplama süreci içine giremediği zaman farklı arayıslara

1 Bu konuda yapılan tarışmalar için bkz. Beyza Bilgin, Eğtuim Biliomi ue Din Egution, Yeni Çizgi Yayunlan, Ankara 1995, 120-128

2 Bilgin, 120 
girecek, belki de sağlıkszz koşullarda elde edilen bilgiler yardımı ile bu sorulanna cevap amacaktur.

Din öğretiminin başlama yaşs ile birlikte ilköğretim çerçevesi içinde yürütülen Din Kültürü ve Ahlak Bilgisi programlann şekillendiren hukuki düzenlemeler ve uygulanan programlar tartş̧maların odağında yer almaktadır. Anayasal düzenleme ile bu derslerin zorunlu olması ve anayasal düzenlemede mezhepler üstü bir çerçeve çizilmesine rağmen oluşturulan programlarda, yazulan ders kitaplarnnda ve uygulamalarda mezhebi bir anlayıșı yansitan unsurlar siyasal ve akademik alanlarda tartışma konusu olmuştur. Ancak giriş bölümünde de belirlediğim gibi bu tartı̧malarda velilerin beklentilerine istenen düzeyde yer verilmemiş, araştırmalar yerine bireysel gözlemlere dayal bilgilere dayanularak değerlendirmeler yapılmıştır.

Velilerin din öğretimine karşı tutumlanı belirlemede bir çok faktörün etkili olduğu kabul edilebilir. Sahip olduklan din anlayışı, din hakkındaki bilgileri, dini tecrübe düzeyleri veya dini tutum düzeyleri bașta olmak üzere, sosyo-kültuirel çevre, belki de o anda kamuoyunun tartıştığı bir konu çerçevesinde yaplan yönlendirmeler, velinin kendi din eğitimi tecrübeleri, yetiştirmekte olduğu çocuğuna kazandırmak istedikleri... vb. bir çok faktör saylarak liste uzatulabilir. Yapulacak araştrmalann tüm bu faktörlerin etkisini birlikte ortaya koyması mümkün olmadığı gibi araştırma sonrasında orya çıkan yeni gelişmeler de beraberinde yeni faktörleri gündemimize sokabilir. Bununla birlikte yine de velilerin din eğitimine ve okullarda yürütülmekte olan din öğretimi etkinliklerine karşı tutumlannun ölçülmesi ve bu tutumları açıklaması muhtemel faktörleri gözlemlerden başlayarak belirlemesi, bu faktörlerin istatistiksel olarak anlamlı olup olmadığıı ve tutumlan açıklama oranları ölçmeyi hedefleyen arasturmalara başlanması gerekmektedir.

Böylece program değerlendirme çalş̧malannda, öğretim çevresinin önemli bir unsuru olan velilerin görüsleri de sisteme bilimsel verilere dayah olarak aktarlmış olacak ve toplumsal kabul de belirli ölçülerde sağlanmış olacaktır. Bu çerçevede araştırmanun problemi, velilerin din öğretimine, özellikle ilköğretim düzeyinde yürütülen Din Kültürü ve Ahlak Bilgisi ögretimine karş̧ tutumlan üzerine kurgulanmıştır. Araşturma boyunca Velilerin Din Kültü̈ rü ze A blak Bilgisi tutum dizeeylerinin dini inanc dizeyi ve din anlayyss darak mubafa. zakarlke dizzeyi ile bir iliskisi buluomakta mdr? sorusuna cevap aranacaktur.

\section{Yöntem}

Araştırmamız için Ankara iline bağh ilköğretim okullannda çocukları olan 102 öğrenci velisi ömeklem olarak belirlenmiştir. Bu belirlemede, Ankara 
Üniversitesi İlahiyat Fakültesi İlköğretim Din Kültürü ve Ahlak Bilgisi Öğretmenliği son sınff öğrencilerinin "Öğretmenlik Uygulaması" dersi için gittikleri ilköğretim okulları ön plana çıkmıştır. Velilere üç bölümden oluşan bir ölçme aracındaki sorulan cevaplamalan istenmiştir. Birinci bölümde velilerin kişisel özelliklerine ilişkin on son yer almaktadır. İkinci bölümde ilköğretim din kültürü ve ahlak bilgisi derslerine karşı tutumların ölçme amacıyla, likert tipi ölçek hazırlama yöntemine dayalı olarak hazırlanan 20 soru bulunmakta, üçüncü bölümde ise dini tutumlan ölçmek için yine likert tipi 24 ölçek sonusu hazırlanmıştur.

Velilerin cevaplaması sonucunda toplanan veri toplama araçlanndaki veriler, SPSS paket programında faktör analizine tabi tutulmuş, ölçeklerdeki alt faktörler belirlendikten sonra faktörlerin kendi aralanndaki ilişkileri ve velilerin kişisel özelliklerine göre farklliaşmalan istatistiksel olarak analiz edilmiştir. $\mathrm{Bu}$ analizler alt faktörler hakkında bilgi verilirken ayn ayn açıklanmış ve yorumlanmıştır.

\section{Hipotez/er}

Araştırma boyunca sınayacağım temel hipotezler şunlardır:

a. Velilerin din kültürü ve ahlak bilgisi derslerine karşı tutum düzeyleri, cinsiyetlerine göre anlamil bir şekilde farklılaşmaktadır.

b. Velilerin din kültürü ve ahlak bilgisi derslerine karşı tutum düzeyleri, sosyo-ekonomik düzeylerine göre anlamlı bir şekilde farkllaşmaktadır.

c. Velilerin din kültürü ve ahlak bilgisi derslerine karşı tutum düzeyleri, almış olduklan eğitimlerine göre anlamlı bir şekilde farklılaşmaktadır.

d. Velilerin din kültürü ve ahlak bilgisi derslerine karşı tutum düzeyleri, mesleklerine göre anlaml bir şekilde farkllaş̧maktadır

e. Velilerin din kültürü ve ahlak bilgisi derslerine karşı tutum düzeyleri, okul dışında din eğitimi alıp almamalanna göre anlamlı bir şekilde farklılaşmaktadir

f. Velilerin din kültürü ve ahlak bilgisi derslerine karşı tutum düzeyleri ile dini tutum düzeyleri arasında pozitif bir ilişki vardır.

g. Velilerin dini tutum düzeylerindeki artışla, din kültürü ve ahlak bilgisi derslerine karşı olan tutumlarındaki artış anlamlı bir şekilde açıklanır. 


\section{Temel Kavramlar}

\section{a. Tutum}

Tutum, sosyal bilimlerde çokça karşımıza çıkan tanımı üzerinde görüş birliği sağlanamayan kavramlardandır. Freedman, Sears ve Carlsmith tutumu "bilişsel ve duygusal ögeleri bulunan ve davranı̧̧sal bir eğilim içeren oldukça kalıcı bir sistem" olarak tanımlamaktadırlar ${ }^{3}$. Smith'in tanımına göre ise " bireye atfedilen ve onun bir psikolojik obje ile ilgili düşünce, duygu ve davranışlannı düzenli bir biçimde oluşturan bir eğilim"dir. Günümüzde de sosyal psikologlar tarafından kabul gören bu tanuma göre tutum, bireye aittir ve onun bir nesneye ilişkin düşünce, duygu ve davranışlanna bir bütünlük, bir tutarlllk getirir. Bireyin tutumlann gözle görebilmek mümkün değildir. Tanımda "bireye atfedilen" ifadesi de, tutumun bireysel bir yaşantı olduğunu ve bunun gözle izlenemediğini vurgulamaktadır5.

Tanımlardaki ortak unsurlardan hareket ettiğimizde bilişsel, duyuşsal ve davranışsal olmak üzere üç öğeden söz etmemiz mümkündür. Bu varsayıma göre bireyin bir konu ile ilgili bildikleri o konuya olumlu bakmasın gerektiriyorsa (bilişsel öğe), birey o konuya ilişkin olumludur (duyuşsal öğe). Bunu sözleri ya da davranışlan ile gösterir (davranıssal öğe) ${ }^{6}$. Tutumlar yalnuzca bir davranış eğilimi ya da sadece bir duygu değil, biliş-duygu-davranuş eğilimi bütünleşmesidir?

\section{Dini Tutum}

Din, bireyin yaşamın anlamlandırmasında kaynak olarak kullandığı önemli olgulardan birisidir. Yaşamın temel sorulannın cevaplandınlmasında dini kaynaklann sunduğu bilgilerden de yararlanılarak duygu ve davranı̧̧ biçimleri geliștirilmektedir. Genellikle de bu tutumlann sosyal hayatın parçası olan farklı alanlardaki tutumlann oluşumunu da etkilemektedir. Çalışmamızın ana eksenini oluşturmadığı için bu alanda ayn bir tutum ölçeği geliştirmemiş olmamıza rağmen, özellikle ülkemizde yapılan dini tutum ölçeği geliştirme çalş̧malannun henüz standardize edilmiş ürünler vermediğini, pilot niteliğinde bir çok çalışma bulunduğunu söylememiz gerekmektedir. Din ve dindarlık

\footnotetext{
Ezel Tavşancl, Tutzonlanm Ö́g̈lmesi ze SPSS ile Veri A nulizi, Nobel Yayuncllk, Ankara 2002, 67

Çăgdem Kağıtçıbaşı, Yeri Insan ue Irsanlar, 10. Bask, Sosyal Psikoloji Dizisi 1, Istanbul 1999, Evrim Basım Yaym Dağtum, 102

Tavşancıl, 67

- M. Inceoğlu, Tutum A lg, Iletizim Verso Yaynctlk, Ankara 1993, 15

Kağıtçıbaşı, 103
} 
ölçmeyi amaçlayan bu çalışmalarn, henüz geniş ömeklemler üzerinde uygulanarak ve tekrarlanarak standardize edilmesi yönünde bir çaba bulunmamaktadır. Bundan dolayı, almış olduğumuz ölçeklerin uygulanması sonrasında birbirine yakın sonuçlar alınamamaktadır. Biz bu alanı çalışma kapsamı dışında tutarak Doç. Dr. Niyazi Akyüz'ün uygulamakta olduğu bir ölçeği teorik yaklaşımlara dayanarak iki ayn grupta düzenleyerek uygulamayı tercih ettik.

\section{Din Eğitimine Karşı Tutum}

Din eğitimi kavram, bireyin dini davranışlannda kendi yaşantılan yoluyla ve kasıth olarak istendik değişme meydana getirme denemeleri ${ }^{8}$ olarak tanumlanmaktadır. Bu tanım, informal etkilenmeleri doğal olarak dışanda bırakmakta ve okulda örgün eğitim çatısı altındaki etkinliklere işaret etmektedir. Dolayssıyla bireylerin din eğitimine karşı tutumlanından söz ettiğimizde okul çatısı altındaki etkinliklere karşı tutumlanından bahsediyonuz demektir.

Ancak insanlann bu tutumlanının iki yönlï olduğunu varsaymaktayım. Birinci yön üzerinde bireylerin din öğretiminin okul çatısı altında olması gerektiğine ilişkin inançlan, bu inancın kaynağı olan bilgileri, bilgi ve inanç doğrultusunda hangi davranışlan sergiledikleri gibi din öğretimine karşı genel bir tutum bulunmaktadır. İkinci yön üzerinde ise mevcut uygulama biçimine ilişin tutumlar bulunmaktadır. Yani uygulamadaki programlardan, ders kitaplanndan memnuniyet, ögretmenlerin yeterliği, okul yönetimlerinin bu öğretim alanına ilişkin ilgilerine karşı tutumlar kastedilmektedir. Öğretim sistemi içinde çocuğu bulunan velilerin din öğretimi alanuna ilişkin tutumlantnun ölçülmesi bu alandaki ilk çalışmadır. Dolayısıyla pilot niteliğinde yapmış olduğumuz bu araşturmadan hareket edilerek geniş örneklemler üzerindeki uygulamalarla daha sağılılı sonuçlar elde edilebileceğini düşünmekteyim.

\section{B. Araştırmaya Katılan Velilerin Kişisel Özellikleri}

Tablo 1. Velisi Olduğu Öğrencinin Sınıfı

\begin{tabular}{c|c|c|c}
\hline \multicolumn{2}{l|}{ Ögrrencinin Sinff } & $f$ & $\%$ \\
\hline 1 & İlkögretim 6 & 55 & 53,9 \\
\hline 2 & illköğretim 7 & 30 & 29,4 \\
\hline 3 & ilköğretim 8 & 17 & 16,7 \\
\hline & Toplam & 102 & 100,0 \\
\hline
\end{tabular}

8 Cemal Tosun, Din Ë̈̆timi Bilimine Giņs, 2. Bask, Pegem-A Yayncllk, Ankara 2002, 23 
Tablo 1'de de görüldüğü gibi araşturmamıza katılan velilerin çocuklan ilköğretim 6, 7 ve 8. sınıfa devam etmektedirler. Bu öğrencilerden \% 53.9'u 6, $\% 29.4$ 'ü 7 ve \%16.7'si ise 8. sunf öğrencisidir.

Tablo 2. Velinin Cinsiyeti

\begin{tabular}{c|c|c|c}
\hline \multicolumn{2}{l|}{ Velinin Cinsiyeti } & $f$ & $\%$ \\
\hline 1 & Erkek & 43 & 42,2 \\
\hline 2 & Kaden & 59 & 57,8 \\
\hline & Toplam & 102 & 100,0 \\
\hline
\end{tabular}

Araşturmaya katulan velilerin \%42.2'si erkek, \%57.8'i ise kadınlardan oluşmaktadır (Bkz. Tablo 2). Bu rakamlar, öğrencilerin okulla ilgili sorunlanyla annelerin babalara oranla daha fazla ilgilendiklerinin de bir göstergesi olarak değerlendirilebilir.

Tablo 3. Gelir (Recode)

\begin{tabular}{c|l|c|c}
\hline \multicolumn{2}{|c|}{ Ögrenci Ailesinin Gelir Durumu } & $f$ & $\%$ \\
\hline 1 & Çok düsük gelir grubu (300 Milyon ve alt) & 16 & 15,7 \\
\hline 2 & Düsük gelir grubu (301-500) & 26 & 25,5 \\
\hline 3 & Orra gelir grubu (501-700) & 13 & 12,7 \\
\hline 4 & Yüksek gelir grubu (701-900) & 20 & 19,6 \\
\hline 5 & Çok yükssek gelir grubu (901 Milyon ve üstü) & 27 & 26,5 \\
\hline & Toplam & 102 & 100,0 \\
\hline
\end{tabular}

Velilerin gelir dağlımına ilişkin rakamlar, açık uçlu olarak alınan rakamlann yukandaki araliklara göre yeniden kodlanması sonucu elde edilmiştir. Velilerin gelirlerinin ortalaması 730 milyon olarak hesaplanmıs ve bu rakamun orta nokta kabul edilerek iki yüz milyon artınlarak ve azaltularak beş gelir grubu oluşturulmuştur.

Tablo 4. Velinin Eğitim Durumu (Recode)

\begin{tabular}{c|l|c|c}
\hline Öğrenci Velisinin Eğitim Durumu & $\mathrm{f}$ & $\%$ \\
\hline 1 & $\begin{array}{l}\text { Okuma Yazma Bilmeyenler, Yalnızca okuryazar olanlar } \\
\text { ve İlkokul Mezunlan }\end{array}$ & 25 & 24,5 \\
\hline 2 & Ortaokul Mezunu & 14 & 13,7 \\
\hline 3 & Lise Mezunu & 34 & 33,3 \\
\hline 4 & Universite Mezunu ve Lisansüstiu Mezunlan & 29 & 28,4 \\
\hline & Toplam & 102 & 100,0 \\
\hline
\end{tabular}

Velilerin eğitim durumlan incelendiğinde en büyük grubu \%33.3 ile lise mezunlannun oluşturduğu görünmektedir. Bu grubu 528.4 ile üniversite ve üstü öğrenime sahip olanlar, \%24.5 ile ilk okul ve altı öğrenim grubu ve $\% 13.7$ ile ortaokul mezunlan izlemektedir. 
Tablo 5. Veli Okul Dışında Din Eğimi Aldı mı?

\begin{tabular}{c|l|c|c}
\hline Öğrenci Velisi Okul Dişında Din Eğitimi Aldı mı? & $f$ & $\%$ \\
\hline 1 & Evet & 53 & 52,0 \\
\hline 2 & Hayır & 49 & 48,0 \\
\hline & Toplam & 102 & 100,0 \\
\hline
\end{tabular}

Araştırmamıza katılan velilerin okul dışında din eğitimi alanlann oran yandan biraz fazladır (\%52.0). Geriye kalan yanya yanıı ise okul dışında din eğitimi almamıştur. Bu din eğitimi ise ailede, camilerde yaz kurslannda veya bir ylllık Kur'an Kurslan aracllğıyla edinilmiştir.

Tablo 6. Veli Dinle Ilgili Kitap Okur mu?

\begin{tabular}{c|l|c|c}
\hline & & $f$ & $\%$ \\
\hline 1 & Evet & 90 & 88,2 \\
\hline 2 & Hayr & 12 & 11,8 \\
\hline & Toplam & 102 & 100,0 \\
\hline
\end{tabular}

Araştırmamıza katılan velilerin tamamına yakın dinle ilgili kitaplar okuduklanı belirtmişlerdir (\%88.2). Dinle ilgili kitap okumadıklanın belirtenlerin oranı ise \%11.8'dir. Bu rakamlar bize araştırma örneklemimizin önemli oranda dinle ilgilenen bir grup olduğunu göstermektedir.

\section{B. Velilerin Illköğretim Din Kültürü ve Ahlak Bilgisi Derslerine Tutumları (Ö/çek Gelistirme)}

"Velilerin İlköğretim Din Kültürü ve Ahlak Bilgisi Derslerine Tutumlarn" ismini vermiş olduğumuz ölçekte bulunan 20 soru temel bileşenler metodu ile incelenerek faktör analizine tabi tutulmuş ve bu ölçekten iki alt boyut elde edilmiştir. Bu sonuçlann yorumlanabilir olup olmadığına ise Ki-Kare Testi sonuçlanna bakarak karar verilmiştir (Barlett Ki-Kare: 811.549; df: 190; $\mathrm{p} \bigotimes .0001$ ). Barlett testi sonuçlan istatistiksel açıdan anlamlı olduğu için faktör analizi sonuçlannin yorumlanabilir olduğu anlaşılmıştır.

Kaiser-Meyer-Olkin katsayısı ise 0.82 olarak ölçülmüştür. Örneklemden elde edilen verilerin yeterligini saptamak amacıyla yapılan bu testte elde edilen değerin 1'e yakunliğı nisbetinde ölçeğin yeterliği yükselmektedir. KMO katsayısı 1-0.90 arası ise yeterlik mükemmel, 0.90-0.80 arasında çok iyi kabul edilmektedir`. Yapılan faktör analizinde elde edilen KMO katsaysı bizim ölçeğimizden elde edilen verilerin çok iyi derecede yeterli olduğunu göstermektedir. Ölçek içindeki bulunan "Çocuğum karşılaştığı problemlerin çözü- 
münde DKAB derslerinden yararlanmaktadır" maddesi her iki faktörde de yüksek yük değerine sahip olduğundan binişik kabul edilmiş ve bu madde çıkartılarak faktör analizi yeniden yapılmıştır.

Tüm testin Cronbach Alfa iç tutarlik değeri ise 0.8309 olarak hesaplanmıştır. Her bir faktör için Alfa değeri ise faktör yük değerlerini gösteren tabloların altunda verilmiştir.

Velilerin likert tipi ölçekte almış olduklan puanlann ortalamalan alındıktan sonra yapılacak değerlendirmede aşağıdaki puan araliklan esas alınacaktır:

1.00-1.79 = Kesinlikle Katilmıorum

1.80-2.59 = Katulmiyorum

2.60-3.39 = Kararsizım

$3.40-4.19=$ Katilyorum

4.20-5.00 = Tamamen Katulyorum

\section{Faktörler ve Faktör Özdeğerleri}

"Velilerin Illköğretim Din Kültürü ve Ahlak Bilgisi Öğretimine Tutum Ölçeği" isimli ölçeği oluşturan faktör adlan, özdeğerleri ve ağırlıklan tablo 8'de verilmiştir. Bu tablodan da izleneceği gibi ölçeğimiz içinde iki ayn alt boyut ortaya çıkmıştır.

Tablo 7. Velilerin ilköğretim Din Kültürü ve Ahlak Bilgisi Derslerine Tutumları Ölçeği Faktör Özdeğcrleri ve Açıkladı̆̆ı Varyans

\begin{tabular}{|c|c|c|c|}
\hline Faktörler & $\begin{array}{l}\text { Faktör } \\
\text { Özdeğerleri }\end{array}$ & $\begin{array}{l}\text { Varyans } \\
\text { Orant (\%) }\end{array}$ & $\begin{array}{c}\text { Kümülatif } \\
(\%)\end{array}$ \\
\hline $\begin{array}{l}\text { 1. Faktör: Illkögretion Din Kültürü ve Ahlak Bilgisi } \\
\text { Ögretim Etkinliklerine Kaşsı Tutum }\end{array}$ & 5.769 & 30.362 & 30.362 \\
\hline 2. Faktör: Din Ögretimine Karş1 Genel Tutum & 2.812 & 14.799 & 45.161 \\
\hline
\end{tabular}

\section{Faktör I: Velilerin Illköğretim Din Kültürü ve Ahlak Bilgisi Öğretiminin Uygu-} lanmasına Yönelik Tutumları

Tablo 8, yapılan faktör analizi sonucunda 1. faktör içinde yüksek yük değerine sahip olan maddelerin ilk analizde ve rotasyon sonrası aldıkları değerleri vermektedir. Tablo incelendiği zaman bu faktör içinde yer alan maddelerin bir kssmının mevcut programlara, uygulamadaki ders kitaplanna, öğretmenlerin kullandıklan materyallere, öğretmen-veli işbirliğine ve okul yönetimlerinin derslerin etkinliği için katkılanna velilerin bakış açlanın merkeze alarak ölçme yapmayı hedeflediği görülmektedir. Diğer maddeler ise programin İslam dininin, diğer dinlerin, mezheplerin, din ve ahlakla ilgili konuların anlatımındaki yeterliğine bakış açısın ölçmede temel almaktadır. 
Tablo 8. Velilerin Illköğretim Din Kültürü ve Ahlak Bilgisi Öğretiminin

Uygulanmasına Yönelik Tutumları

\begin{tabular}{|c|c|c|c|c|}
\hline & $\begin{array}{l}\text { Faktör I: Ilköğnetim Din Külrürü ve Ahlak } \\
\text { Bilgisi Ögretiminin Uygulanmasina Yönelik } \\
\text { Turum Maddeler }\end{array}$ & $\begin{array}{l}\text { Birinci Falkör } \\
\text { Yük Değeri }\end{array}$ & $\begin{array}{l}\text { Rotasyon } \\
\text { Sonrasi }\end{array}$ & $\begin{array}{c}\text { Madde } \\
\text { Toplam } \\
\text { Korelasyonu }\end{array}$ \\
\hline 1 & $\begin{array}{l}\text { Din Külüiri ve Ahlak Bilgisi Dersleri mevcut } \\
\text { programlar açısindan yetedidir }\end{array}$ & .717 & .716 & .6333 \\
\hline 2 & $\begin{array}{l}\text { Din Kültürü ve Ahlak Bilgisi ders kitaplan bu } \\
\text { haliyle yeterlidir }\end{array}$ & .706 & .715 & .6287 \\
\hline 3 & $\begin{array}{l}\text { Din Kültürï ve Ahlak Bilgisi dersleri Islam } \\
\text { dini hakkanda yeterince bilgi vermeksedir }\end{array}$ & .759 & .760 & .6999 \\
\hline$\overline{4}$ & $\begin{array}{l}\text { Din Kültürü ve Ahlak Bilgisi Derslerini } \\
\text { okutan ögretmenler bu dersin sunumunda } \\
\text { yeterlidir }\end{array}$ & .630 & .636 & .5537 \\
\hline 5 & $\begin{array}{l}\text { Din Külü̈ü ve Ahlak Bilgisi ögretmenlerinin } \\
\text { kullandiklan materyaller yeterlidir }\end{array}$ & .771 & .768 & .6957 \\
\hline 6 & $\begin{array}{l}\text { Din Kültünü ve Ahlak Bilgisi derslerinin etkin } \\
\text { yürütülmesi için okul idareleri gereken ilgiyi } \\
\text { göstermektedir }\end{array}$ & .759 & .769 & .7081 \\
\hline 7 & $\begin{array}{l}\text { Din Külürü ve Ahlak Bilgisi ögretmenlen } \\
\text { derslerin daha etkin yürütülmesi için velilerle } \\
\text { işbirliği sağlamaktadır }\end{array}$ & .369 & .351 & .3033 \\
\hline 8 & $\begin{array}{l}\text { Din Küluirü ve Ahlak Bilgisi dersleri Islamiyet } \\
\text { dişındaki dinlerin anlatuminda yeterlidir }\end{array}$ & .502 & .500 & .4289 \\
\hline 9 & $\begin{array}{l}\text { Din Kültürü ve Ahlak Bilgisi Derslen İslami- } \\
\text { yet içindeki farkh mezhep ve dini anlayışlann } \\
\text { anlatuminda yeterlidir }\end{array}$ & .720 & .703 & .6333 \\
\hline 10 & $\begin{array}{l}\text { Din Külrürü ve Ahlak Bil. dersleninde sınif } \\
\text { drşı etkinlikler (cami vb. dini yapulann ziyaret } \\
\text { edilmesi) yeterince kullanulmaktadır. }\end{array}$ & .507 & .506 & .4432 \\
\hline 11 & $\begin{array}{l}\text { Çocuğumun edinmesi geneken dini bilgiler } \\
\text { açısından okuldaki Din Külrürü ve Ahlak } \\
\text { Bilgisi dersleri yeterlidir }\end{array}$ & .757 & .764 & .6776 \\
\hline 12 & $\begin{array}{l}\text { Din Kültürü ve Ahlak Bilgisi ögretimi, din ve } \\
\text { ahlakkla ilgili konularn sunumu açısından bu } \\
\text { haliyle iyidir }\end{array}$ & .679 & .692 & .5924 \\
\hline
\end{tabular}

Cronbach Alpha: .8809

Birinci faktör içinde yer alan tutum maddelerinde en yüksek tutum düzeyi dersi okutan öğretmenlerin sunumunda yeterli oldukları yargısında karşımıza çıkmaktadır. Bu madde ile birlikte DKAB öğretiminin din ve ahlakla ilgili konularn sunumunda yeterli olduğu, DKAB'in İslam dini hakkında yeterince bilgi verdiği, $D K A B$ öğretiminde kullanulan materyallerin yeterli olduğu ve nihayet $\mathrm{DKAB}$ programlanun yeterli olduğu velilerin birbiri ardınca yüksek tutum düzeylerine sahip olduğu maddeler olarak karşımıza çıkmaktadur. Say diğımız bu maddelerin tamaminda velilerin tutum düzeyi "katdlyorum" kategorisine karşlik gelmektedir. Tablo 10 'da sunmuş olduğumuz madde ortalamalı incelendiği zaman sadece $\mathrm{DKAB}$ dersleri öğnetimi çerçevesinde yürütü- 
len sınuf dışı etkinliklerin yeterliğine ilişkin tutum düzeyi ortalaması "katulmyorum" kategorisine karşllk gelmekte, diğer maddeler ise orta düzey olan "kararsızım" kategorisine eşdeğer olarak karşımıza çıkmaktadır.

Ölçeğimizin faktör analizi sonucu çıkan 1. faktör'de yer alan maddelerin “illköğretim Din Kültürü ve Ahlak Bilgisi Öğretiminin Uygulanmasına Yönelik Tutum"u ölçmedeki güvenirliğinin test edilmesi sonucu elde edilen Cronbach Alfa iç tutarluk değeri $0.88^{\prime}$ dir. Bu rakam bize 1. faktör'de ortaya çıkan ölçeğin yüiksek düzeyde güvenilir olduğunu göstermektedir.

Tablo 9. Ilköğretim Din Kültürü ve Ahlak Bilgisi Öğretim

Etkinliklerine Karşı Tutum Maddeleri Ortalamaları

\begin{tabular}{|c|c|c|c|c|c|c|}
\hline & Maddeler & f & Mean & Std & Skewness & $\begin{array}{l}\text { Std. } \\
\text { Error }\end{array}$ \\
\hline 1 & $\begin{array}{l}\text { DK AB okutan ögretmenler dersin sunumun- } \\
\text { da yeterlidir }\end{array}$ & 102 & 3,80 & 1,025 &,- 721 & 239 \\
\hline 2 & $\begin{array}{l}\text { DKAB, din ve ahlakda ilgili konulann } \\
\text { sunumunda bu haliyle iyidir }\end{array}$ & 102 & 3,59 & 958 &,- 670 &, 239 \\
\hline 3 & $\begin{array}{l}\text { DKAB islam dini hakkanda yeterince bilgi } \\
\text { vermektedir }\end{array}$ & 102 & 3,46 & 1,248 &,- 439 &, 239 \\
\hline 4 & $\begin{array}{l}\text { DKAB ögretmenlerinin kullandiğ materyaller } \\
\text { yetertidir }\end{array}$ & 102 & 3,41 & 1,047 &,- 263 & 239 \\
\hline 5 & DKAB programlan yeterlidir & 102 & 3,40 & 1,204 &,- 441 &, 239 \\
\hline 6 & $\begin{array}{l}\text { DKAB Islam dini dissindaki dinlerin anlatr- } \\
\text { minda yeteridir }\end{array}$ & 102 & 3,31 & 1,186 &,- 235 &, 239 \\
\hline 7 & $\begin{array}{l}\text { DKAB öğretmenler velilerle işbirliği yapmak- } \\
\text { tadır }\end{array}$ & 102 & 3,31 & 1,177 &,- 080 & 239 \\
\hline 8 & $\begin{array}{l}\text { DKAB etkinliği için okul idareleri yeterli ilgi } \\
\text { göstermektedir }\end{array}$ & 102 & 3,21 & 1,221 &,- 138 &, 239 \\
\hline 9 & $\begin{array}{l}\text { Çocugumun alması gereken bilgiler açısından } \\
\text { DKAB yeterlidir }\end{array}$ & 102 & 3,18 & 1,206 &,- 140 &, 239 \\
\hline 10 & DKAB ders kitaplan yeterlidir & 102 & 3,18 & 1,206 & $\therefore, 175$ & 239 \\
\hline 11 & $\begin{array}{l}\text { DKAB Islam içindeki farkd mezhep ve dini } \\
\text { anlayş̧lann sunumunda yeterlidir }\end{array}$ & 102 & 3,08 & 1,166 &,- 155 &, 239 \\
\hline 12 & $\begin{array}{l}\text { DKAB derslerinde sinuf disı etkinlikler yeter- } \\
\text { lidir }\end{array}$ & 102 & 2,53 & 1,398 & .581 & 239 \\
\hline
\end{tabular}

\section{II. Faktör: Din Öğretimine Karşı Genel Tutum Maddeleri}

Tablo 10, yaptı̆ı̆ız faktör analizi sonucunda 1 . faktör içinde yüksek yük değerine sahip olan maddelerin ilk analizde ve rotasyon sonrası aldıklan değerleri vermektedir. Tablo incelendiği zaman bu faktör içinde yer alan maddelerin bir kısmının velilenin örgün eğitim içinde zorunlu din öğretimine karşı tutumlannı ölçmeye yönelik olduğu görülebilir. Velinin DKAB derslerinin zorunluluğunu savunma davranışı, birinci sınıtan itibaren zorunlu olması gerektiğini savunması, ders saatlerinin artınlması gerektiğini savunması gibi maddeler bunlara ömektir. Maddelerin bir kısmı ise velisi olduğu öğrenciyle 
bu ders çerçevesindeki ilgisini ölçmeye yarayan maddeler bulunmaktadır. Bu maddeler aracllı̆ıyla velinin bu derse karşı olan ilgisi ölçülmeye çalı̧ılmaktadır. Dersin öğrencinin davranışlanına olumlu katkı sağladığı düş̧üncesi, öğrencinin başansızlığının veliyi üzmesi, çocuğun ders kapsamında neler öğrenildiğinin merak edilmesi gibi tutum maddeleri de söz konusu ilginin ölçülmesini hedeflemektedir.

Tablo 10. Din Öğretimine Karşı Gencl Tutum Maddeleri

\begin{tabular}{|c|c|c|c|c|}
\hline & $\begin{array}{l}\text { Faktör II: Din Öğretimine Karş̧ Genel Tutum } \\
\text { Maddeleri }\end{array}$ & $\begin{array}{l}\text { Bininci Faktör } \\
\text { Yük Değeri }\end{array}$ & $\begin{array}{l}\text { Rotasyon } \\
\text { Sonrasi }\end{array}$ & $\begin{array}{c}\text { Madde } \\
\text { Toplam } \\
\text { Korelasyonu }\end{array}$ \\
\hline 1 & $\begin{array}{l}\text { DKAB Derslerinin İlkögretim 1. sinuftan itiba- } \\
\text { ren zorunlu olması gerekir }\end{array}$ & .538 & .526 & .3479 \\
\hline 2 & $\begin{array}{l}\text { Cocugrumun DKAB Dersinde Başarsszluğ beni } \\
\text { rahatsiz eder }\end{array}$ & .587 & .587 & .4129 \\
\hline 3 & $\begin{array}{l}\text { DK AB Dersleri çocugumun davranışannda } \\
\text { olumlu bir katk sağlamakcadır }\end{array}$ & .502 & .534 & .4097 \\
\hline 4 & $\begin{array}{l}\text { DKAB derslerinin okulda zorunlu dersler } \\
\text { arasinda olması gerektiğini her yerde savunurum }\end{array}$ & .711 & .717 & .5627 \\
\hline 5 & DKAB derslerinin saatleri arunlmalidur & .673 & .656 & .4236 \\
\hline 6 & $\begin{array}{l}\text { Çocugumun DK AB derslerinde neler öğrendik- } \\
\text { lerini merak ederim }\end{array}$ & .723 & .726 & .5314 \\
\hline 7 & $\begin{array}{l}\text { Cocuğum } \mathrm{DKAB} \text { derslerinde ögrendiklenini } \\
\text { paylassır }\end{array}$ & .495 & .522 & .3713 \\
\hline
\end{tabular}

Cronbach Alfa: .7164

Din öğretimine karşı tutum maddelerinin ortalamalan incelendiği zaman çocuğun $\mathrm{DKAB}$ derslerinden başansızlığından üzüntü duyması ile ilgili olan maddedeki tutum düzeyinin "kesinlikle katilyorum" kategorisine karşlik geldiği görülmektedir. Yine tutum ortalamalanna bakuldığında DKAB'in zorunluluğu, çocuklann davranışlannda olumlu etki yaptığı ve çocuklann $D K A B$ derslerinde neler öğrendiğinin merak edilmesi maddelerinin "katulyorum" kategorisinde kalmasına rağmen küçük bir farkla "kesinlikle katulyorum" un dışında kaldığı görülmektedir (Bakınız: Tablo 11). Bu faktör içinde yer alan tutum puanlannda en düşüğü $\mathrm{DKAB}$ ders saatlerinin artırlması ile ilgili olanda olmasına rağmen buradaki düzey bile "katıllyorum" kategorisine karşlltk gelmektedir. İkinci faktördeki tutum düzeyleri birinci faktöre göre belirgin bir yüksekliks arz etmektedir.

Tablo I I. Din Öğretimine Karşı Genel Tutum Maddeleri Ortalamaları

\begin{tabular}{c|l|c|c|c|c|c}
\hline & Maddeler & $\mathrm{N}$ & Mean & Std & Skewness & $\begin{array}{c}\text { Std. } \\
\text { Error }\end{array}$ \\
\hline 1 & $\begin{array}{l}\text { Cocuğumun DKAB derslerinde başarsızliğ1 } \\
\text { beni üzer }\end{array}$ & 102 & 4,35 &, 981 & $-1,981$ &, 239 \\
\hline 2 & $\begin{array}{l}\text { DKAB derslerinin zorunlu olmasi gerektiğgini } \\
\text { her yerde savununum }\end{array}$ & 102 & 4,19 &, 972 & $-1,440$ &, 239 \\
\hline
\end{tabular}




\begin{tabular}{|c|c|c|c|c|c|c|}
\hline & Maddeler & $N$ & Mean & Std & Skewness & $\begin{array}{l}\text { Std. } \\
\text { Error }\end{array}$ \\
\hline 3 & $\begin{array}{l}\text { DKAB dersleri çocugurumun davranı̧̧anna } \\
\text { olumblu etki yapmaktadır }\end{array}$ & 102 & 4,16 & 1,002 & $-1,345$ &, 239 \\
\hline 4 & $\begin{array}{l}\text { DKAB derslerinde çocuğumun neler ögrendi- } \\
\text { gini merak ederim }\end{array}$ & 102 & 4,16 & $\overline{853}$ & $-1,090$ & 239 \\
\hline 5 & $\begin{array}{l}\text { DKAB ilkögretim 1. suruftan itibaren zorunlu } \\
\text { olmalıdır }\end{array}$ & 102 & 3,80 & 1,211 &,- 877 &, 239 \\
\hline 6 & $\begin{array}{l}\text { Cocuğum DKAB derslerinde ögrendiklerini } \\
\text { benimle paylașr }\end{array}$ & 102 & 3,68 & 1,252 &,- 843 &, 239 \\
\hline 7 & $\mathrm{DK} \mathrm{AB}$ ders saatler arturimalidir & 102 & 3,62 & 1,126 &,- 384 &, 239 \\
\hline
\end{tabular}

\section{Velilerin Dini Tutumları}

Velilerin dini tutumlanı ölçmek amacıyla bir ölçek geliştirme çalışması yapmak bizim çalışmazın sınurlan dışında olduğu için yapılmış çalışmalardan yararlanma yolunu tercih ettik. Bu anlamda Doç. Dr. Niyazi Akyüz'ün İlahiyat Fakültesi öğrencileri üzerinde yapmakta olduğu bir araştırmada din anlayışlanı belirlemeyi amaçlayan skaladan seçilen 24 soruluk ölçek belirledik. Bu 24 sorudan 11 tanesi inanç ve ibadetlere ilişkin ilahiyat teorisinde gerekli olduğu üzerinde görüş̧ birliği bulunan maddelerden oluştu. Diğer 13 tanesi ise ilahiyat çalışmalannda üzerinde görüş birliği bulunmayan ama geleneksel dindarlı̆̆n önemli göstergeleri arasında bulunan maddelerden belirlendi. Bu anlamda dini tutumlar içinden ikji ayn ölçek, teorik yaklaşımlara dayalı olarak ortaya kondu. Ancak bu iki faktör dini tutumlan ölçme amacıyla oluşturdugumuz ölçek için yapılan faktör analizi sonucunda alt faktörler olarak çıkmad. Dindarlık maddelerinden " $\mathrm{Hz}$. Muhammed Allah'ın Peygamberidir" ifadesi faktör yük değerinin 0.30 'un altında olması nedeniyle ölçek dışında bırakalmış ve burada elimizde 10 madde kalmıştır. Şimdi teoriye dayalı olarak belirlediğimiz faktörlerin güvenilirlik çalışması sonuçlannı veriyonuz.

\section{Velilerin Dini Tutumları}

Velilerin dini inanca ilişkin tutumlann ölçmek amacıyla on bir maddelik tek faktörlï bir ölçek faktör analizine alındı. Analiz sonucunda bir madde (" $\mathrm{Hz}$. Muhammed Allah'in Peygamberidir") 0.30 'un altında yük değeri aldığ için ölçekten çıkartıldı. Bu madde çıkartıldıktan sonra yeniden yapılan tek faktörlï analiz sonucunda dini inanca ilişkin tutumların faktör yük değerleri ve madde toplam korelasyonu aşağıdaki gibi oluştu. 
Tablo 12. Dini Tutum Maddeleri

\begin{tabular}{c|l|c|c}
\hline & 1. Fakıör. Dini Tutum Maddeleri & $\begin{array}{c}\text { Fakö̈r Yük } \\
\text { Değen }\end{array}$ & $\begin{array}{c}\text { Madde Toplam } \\
\text { Korelasyonu }\end{array}$ \\
\hline 1 & Kur'an'da anlaulan her şey doğnudur & .818 & .8346 \\
\hline 2 & Ramazanda oruç tutmak benim için önemlidir & .764 & .7302 \\
\hline 3 & Kư'an günümüze kadar değismeden gelmiştir & .755 & .6905 \\
\hline 4 & Günde beş vakit namaz kulmak benim için önemlidir & .750 & .7198 \\
\hline 5 & Islam'in yasakladı̆̆ konulardan uzak durmak genekir & .736 & .7305 \\
\hline 6 & Ahiret günü ve ölümden sonra hayat vardır & .720 & .6315 \\
\hline 7 & Hz. Muhammed'in sevgisini kazanmak için gayret göster- & .709 & .6567 \\
\hline 8 & mek gerekir & & \\
\hline 9 & Allah'in varlğı̆na inanmak gerekir & .695 & .6435 \\
\hline 10 & Allah'in sevgisini kazanmak için gayret göstermek gerekir & .625 & .6007 \\
\hline
\end{tabular}

Cronbach Alpha: 8971

Dini inançla ilgili maddelerin tamamunda tutum düzeyleri "kesinlikle kathlyorum" kategorisinin içinde yer almaktadir. En yüksek tutum Allah'a inanmakla ilgili olan, en düsüğü ise günde beş vakit namazla ilgili olanıdır (Bakınz: Tablo 13).

Tablo 13. Dini Tutum Maddelerinin Ortalamaları

\begin{tabular}{|c|c|c|c|c|c|}
\hline & Madde & $\mathrm{N}$ & Mean & Std & Skewness \\
\hline 1 & Allah'in varlügna inanmak gerekir & 102 & 4,87 & 539 & $-5,518$ \\
\hline 2 & Allah'un sevgisini kazanmak benim için önemlidir & 102 & 4,80 &, 468 & $-2,396$ \\
\hline 3 & Kur'an'da anlatulan her şey doğnudur & 102 & 4,79 &, 551 & $-2,966$ \\
\hline 4 & $\begin{array}{l}\text { Hz. Muhammed'in sevgisini kazanmak için gayret } \\
\text { göstermek gereklidir }\end{array}$ & 102 & 4,78 &, 519 & $-2,834$ \\
\hline 5 & İhriyaç sahiplerine yandımcı olmak benim için önemlidir & 102 & 4,75 &, 432 & $-1,203$ \\
\hline 6 & İslam'in yasakladığ konulardan uzak durmak gerekir & 102 & 4,72 & .666 & $-3,098$ \\
\hline 7 & Ramazan ayında oruç tutmak benim için önemlidir & 102 & 4,72 & .651 & $-3,160$ \\
\hline 8 & Ahiret günü ve ölümden sonra hayat vardır & 102 & 4,70 &, 657 & $-2,366$ \\
\hline 9 & Kur'an günümüze kadar değişmeden gelmişưr & 102 & $4, \overline{56}$ &, 885 & $-1,972$ \\
\hline 10 & Günde beş vakit namaz kalmak benim için önemlidir & 102 & 4,44 & 929 & $-1,828$ \\
\hline
\end{tabular}

\section{Geleneksel-ilmihalci Tutum}

Geleneksel-ilmihalci tutum'dan kastedilen, bireylerin dini inanç ve düşüncelerinin şekillenmesinde geleneksel din öğretiminde belli bir dönemde etkin olan ilmihallerdeki dini bilgiler ve bu ilmihallerdeki din anlayışıdır. Așağıdaki ölçekte yer alan maddeler, 1980'lere kadar piyasada bulunan çeşitli ilmihallerden geleneksel anlayışın uç noktası olarak kabul edilebilecek konular arasındaki görü̧̧lerden seçilmiştir. Yakın tarihlerde bu konular artık ilahiyat alanınun tartışmalı konulan arasına girmiş, kimisinde ise tamamen tersine görü̧sler 
üzerinde uzlaşma sağlanmıştır. Bu konulann İslam Hukuku açısından tartışılması bu araştırmanın alanı dışındadır. Benim varsayımım, bu maddelerin belli bir dönemde egemen olan din anlayışın temsil eden düşünceler olduğudur.

Tablo 14. Geleneksel-ilmihalci Tutum Maddeleri

\begin{tabular}{|c|c|c|c|}
\hline & 2. Faktör: Geleneksel-ilmihalci Dini Tutum & $\begin{array}{l}\text { Faktör Yük } \\
\text { Değen }\end{array}$ & $\begin{array}{c}\text { Madde Toplam } \\
\text { Korelasyonu }\end{array}$ \\
\hline$\overline{1}$ & Namazlann sünnetinin de kelınması gereklidir & .821 & .7236 \\
\hline 2 & Sünnet olan ibadetleri yerine getirmek benim için önemlidir & .778 & .6839 \\
\hline 3 & Ramazanda teravih namazın kalmak benim için önemlidir & .745 & .6383 \\
\hline 4 & Faizli her türlï alışverişten uzak durmak gerekir & .721 & .6624 \\
\hline 5 & Erkeklerin altın takunması Íslam'a göre yasaktır & .700 & .6608 \\
\hline 6 & Resim bulunan eve melekler girmez & .681 & .6445 \\
\hline 7 & Namaz kilmayanlarun dini inanci zayfur & .657 & .6126 \\
\hline 8 & Kurban dinin bir emridir & 645 & .5685 \\
\hline 9 & Dini nikah olmadan resmi nikah geçerli olmaz & .600 & .5345 \\
\hline 10 & Dini hükümler şartar değişince değismez & .579 & .5141 \\
\hline 11 & Guma namazi klmayanlar Müslüman saylmaz & .536 & .5034 \\
\hline 12 & Kolonya abdesti bozar & .493 & .4453 \\
\hline 13 & Çok kadınla evlilik İslam'a uygundur & .420 & .3302 \\
\hline
\end{tabular}

Cronbach Alpha: .8774

Geleneksel-ilmihalci tutum olarak isimlendirdiğimiz bu boyutta yer alan maddeler içinde en yüksek tutum düzeyi kurban ibadeti, namazın sünnetleri, sünnet hükmündeki diğer ibadetlerle ilgili maddelerde karşımıa çıkmaktadır. Şartlar değişince dini hükümler değişmez yargısı, teravih namazı ve faizli alışverişten uzak durma davranışıyla birlikte bu maddelerde tutum düzeyleri "tamamen katulyorum" kategorisi içinde yer almaktadır. Cuma namazı kılmayanlar Müslüman saylmaz ve çok evlilik İslam'a göre uygundur yarglan ise en düşük tutum düzeyleri ile "katılmıyorum" kategorisi içinde karşımıza çıkmaktadır (Tablo 15).

Tablo 15. Geleneksel-ilmihalci Dini Tutum Maddeleri Ortalamaları

\begin{tabular}{|c|c|c|c|c|c|}
\hline & Maddeler & $\mathbf{N}$ & Mean & Std & Skewness \\
\hline 1 & Kurban dinin bir emridir & 102 & 4,51 &, 805 & $-1,773$ \\
\hline 2 & Namazlann sünnetlerinin de kulunası gereklidir & 102 & 4,46 &, 852 & $-1,932$ \\
\hline 3 & $\begin{array}{l}\text { Sünnet olan ibadeten de yerine getimek benim için } \\
\text { önemlidir }\end{array}$ & 102 & 4,40 & 774 & $-1,363$ \\
\hline 4 & Dini hüloümler sartlar değisince değişmez & 102 & 4,33 & 926 & $-1,327$ \\
\hline 5 & $\begin{array}{l}\text { Ramazanda teravih namazını kulmak benim için önem- } \\
\text { lidir }\end{array}$ & 102 & 4,27 & ,946 & $-1,367$ \\
\hline 6 & Faizli her türlü alş̧verişten uzak durmak gerekir & 102 & 4,26 &, 943 & $-1,351$ \\
\hline 7 & Dini nikah olmadan resmi nikah geçerli olmaz & $10 \overline{2}$ & 3,27 & 1,415 &,- 181 \\
\hline 8 & Erkeklerin altun takması Islam'a göre yasaktır & 102 & 3,25 & 1,240 &,- 214 \\
\hline
\end{tabular}




\begin{tabular}{c|l|c|c|c|c}
\hline & Maddeler & $\mathrm{N}$ & Mean & Std & Skewness \\
\hline 9 & Namaz kalmayanlann dini inanci zayfur & 102 & 3,17 & 1,365 &,- 094 \\
\hline 10 & Kolonya abdesti bozar & 102 & 3,08 & 1,224 &,- 020 \\
\hline 11 & Resim bulunan eve melekler giremez & 102 & 2,74 & 1,297 &, 258 \\
\hline 12 & Cuma namazi klamayanlar Müsliman saylmaz & 102 & 2,40 & 1,196 &, 838 \\
\hline 13 & Cok kadinla evlilik Islam'a göre uygundur & 102 & 2,23 & 1,371 &, 829 \\
\hline
\end{tabular}

\section{Velilerin Illö̈gretim Din Kültürü ve Ahlak Bilgisi Dersi Uygulamalarına Karşı} Tutumları ve Din Öğretimine Karşı Tutumları Ile Dini Tutumları Arasındaki iliski

Velilerin İlköğretim Din Kültürü ve Ahlak Bilgisi öğretimine karşı tutumlan ile ilgili faktörler ve dini inanç tutumlan ile ilgili faktörlenin birbirleriyle ilişkini belirlemek amacıyla yapılan korelasyon testi sonucunda araştırmamızın temel varsayımlanndan birisi olan din kültürü ve ahlak bilgisi öğretimine karşı olan tutumlanın dini tutumlara bağh olarak değiştiği varsayımı doğrulanmıştır. DKAB dersi uygulamalanna ilişkin olan faktörümüzle diğer faktörler arasında bir ilişki gözlenmemekle birlikte din öğretimine karşı genel tutumu ortaya koyan faktör, hem dini inanç tutumlan ( $r=0.53 ; \mathrm{p} \diamond .0001)$ hem de geleneksel-ilmihalci tutumla $(\mathrm{r}=0.47 ; \mathrm{p} \varangle .0001)$ orta düzeyde anlaml bir pozitif bir ilişki içindedir (Bakunız: Tablo 17). Aynca araştırma konumuz içinde bulunmamakla birlikte yapılan analiz sonucunda dini inanç tutumlan ile geleneksel-ilmihalci tutumlar arasında da orta düzeyde ve pozitif yönde anlamlı bir ilişki belirlenmiştir $(r=0.64 ; p \infty 0001)$. Bir sonraki bölümde yapacağımız Regresyon analizinde korelasyon analizi sonuçlanna göre aralarında ilişki bulunan faktörler üzerinde durulacaktır.

\section{E. Velilerin Din Öğretimine Karşı Genel Tutumlarının Dini Inanç ve Geleneksel-} IImihalci Tutumlara Göre Regresyon Analizi

Tablo 16. Din Öğretimi Tutumları ile Dini İnanç ve Geleneksel-ilmihalci

Tutum Düzeyleri Arasında Regresyon Analizi Sonuçları

\begin{tabular}{c|c|c|c|c}
\hline Model & $\mathrm{R}$ & R Square & Adjusted R Square & Std. Error of the Estimate \\
\hline 1 &, $556(\mathrm{a})$ &, 309 &, 296 &, 54397 \\
\hline
\end{tabular}

a Predictors: (Constant). Gelenekscl-ilmihalci Dini Tutum Ortalamaları, Dini Tutum Ortalamalar

ANOVA(b)

\begin{tabular}{c|l|l|l|l|l|l}
\hline Model & & Sum of Squares & Df & Mean Square & $F$ & Sig. \\
\hline 1 & Regression & 13,130 & 2 & 6,565 & 22,186 &, $000(\mathrm{a})$ \\
\hline & Residual & 29,294 & 99 &, 296 & & \\
\hline & Total & 42,424 & 101 & & & \\
\hline
\end{tabular}

a Predictors: (Constant). Gcleneksel-ilmihalci Dini Tutum Ortalamaları, Dini Tutum Ortalamalan

b Dependent Variable: Din Ögretimi Tutum Ortalamaları 


\begin{tabular}{|c|c|c|c|c|c|c|}
\hline \multirow[t]{2}{*}{ Model } & & \multicolumn{2}{|c|}{ Unstandardized Coefficients } & \multirow{2}{*}{$\begin{array}{c}\text { Standardized } \\
\text { Coefficients } \\
\text { Beta }\end{array}$} & \multirow[t]{2}{*}{$\mathbf{T}$} & \multirow[t]{2}{*}{ Sig. } \\
\hline & & B & Std. Error & & & \\
\hline \multirow[t]{3}{*}{1} & (Constant) & .618 & .579 & & 1,068 &, 288 \\
\hline & $\begin{array}{l}\text { Dini Tutum } \\
\text { Ortalamalan }\end{array}$ & ,563 & 155 & ,391 & 3,620 &, 000 \\
\hline & $\begin{array}{l}\text { Geleneksel- } \\
\text { İlmihalci Dini } \\
\text { Tutum Ortalamalan }\end{array}$ & 203 &, 100 & ,219 & 2,024 &, 046 \\
\hline
\end{tabular}

a Dependent Variable: Din Öğrctimi Tutum Ortalamaları

Tablo 16 'da sunulan veriler birlikte incelendiğinde dini inanç ve gelenekselilmihalci tutumlann din öğretimine karșı tutumlan önemli oranda etkilediği görülmektedir. Dini inanç ve geleneksel-ilmihalci tutumlar birlikte din ögretimine karş̧ tutumlann \%31'ini açıklamaktadır $\left(\mathrm{R}^{2}=0.31\right)$. Bu rakamlar bize din öğretimine karşı genel tutumu sadece dini inanca ilişkin tutumlarla açıklamanın mümkün olmadığın, dinin inanç dışında bir takım faktörlerin din öğretimine karşı tutumların oluşmasında etken olduğunu göstermektedir. Din öğretimine karşı tutumlann oluşmasında etken olan ve araştırmamızda açıklanamayan bu faktörlerin başka araştırmalarla ortaya konması gerekmektedir.

Dini tutum ortalamalanndaki her 1 birim artı̧̧ din öğretimine karşsı genel tutumu 0.56 birim artırmakta, geleneksel-ilmihalci tutumdaki her 1 birim artıs ise din öğretimine karşı genel tutumda 0.20 artı̧̧a sebep olmaktadır (Din Öğretimine Karş̣1 Genel Tutum $=B(0.618)+0.563$ Dini Tutum +0.203 Geleneksel Din Anlayş̧ı).

\section{E. Din Eğitimi Tutumları-Ilköğretim Din Kültürü ve Ahlak Bilgisi Tutumları-Dini} Tutum ve Geleneksel Dini Tutum Düzeylerinin Velilerin Kişisel Özelliklerine Göre Farklılaşması

\section{Velilerin Dini Inanç Tutumlarının Okul Dışında Din Eğitimi Alıp Almadığına Göre Farklılaşması}

Tablo 18. Velilerin Dini İnanç Tutumlarının Okul Dışında Din Eğitimi Alıp Almadığına Göre Farklılaşması (ilişkisiz t-test)

\begin{tabular}{l|l|l|l|l|l}
\hline Veli Okul Dıs̆unda Din Ĕgimi Aldı m? & N & Mean & S & Sd & T \\
\hline Evet & 53 & 4,8358 &, 38435 & 100 & $2,953 \bullet$ \\
\hline Hayır & 49 & 4,5816 &, 48291 & & \\
\hline$p \varangle 0001$ & & &
\end{tabular}

Tablo 18'deki veriler incelendiği zaman velilerin dini inanç tutumlannın okul dışında din eğitimi alıp almadığına göre anlamlı bir şekilde farklılaştığı 
görülmektedir. Velilerden okul dışında din eğitimi almış olanlann dini inanç tutumlan, okul dışında din eğitimi almayanlara göre yüksektir.

\section{Velilerin Geleneksel-ilmihalci Tutumlarının Okul Dışında Din Eğitimi Alıp Almamalarına Göre Farklıaşması}

Tablo 19'da sunulan veriler incelendiği zaman velilerin geleneksel-ilmihalci tutumlanının okul dışında din eğitimi alıp almamalanna göre istatistiksel açıdan anlamlı bir şekilde farklllaştı̆̆ görülmektedir. Okul dışında din eğitimi alan velilerin geleneksel-ilmihalci tutum düzeyleri almayanlara göre yüksektir.

Tablo 19. Velilerin Geleneksel-ilmihalci Tutumlarının Okul Dışında

Din Eğitimi Alıp Almamalarına Göre Farklılaşması (ilişsisiz t-test)

\begin{tabular}{l|l|l|l|l|l}
\hline Veli Okal Dışında Din Eğimi Aldı m? & N & Mean & S & Sd & $t$ \\
\hline Ever & 53 & 3,7402 & 71355 & 100 & $2,667 \bullet$ \\
\hline Hayır & 49 & 3,3815 &, 63858 & & \\
\hline
\end{tabular}

$\bullet p \odot .01$

\section{Velilerin Dini Inanç Tutumlarının Dinle ilgili Kitap Okumasına Göre}

Farklılasması

Tablo 20'deki veriler birlikte incelendiği zaman velilerin dini inanç tutumlannın dinle ilgili kitap okuyup okumadıklanna göre anlaml bir şekilde farkllaştığı görülmektedir. Dinle ilgili kitap okuyan velilerin dini inanç tutum düzeyleri okumayanlara göre yüksektir.

Tablo 20. Velilerin Dini Inanç Tutumlarının Dinle ilgili Kitap Okumasına

Göre Farklılaşması (ilişkisiz t-test)

\begin{tabular}{l|l|l|l|l|l}
\hline Veli Dinle ilgili Kitap Okur mu? & N & Mean & S & Sd & t \\
\hline Evet & 90 & 4,0857 &, 57375 & 100 & $4,283 \bullet$ \\
\hline Hayr & 12 & 3,2976 &, 77162 & & \\
\hline$P \varangle .0001$ & & & & &
\end{tabular}

\section{Velilerin Ilköğretim Din Kültürü ve Ahlak Bilgisi Öğretimi Uygulamalarına} Karşı Tutumlarının Ekonomik Durumlarına Göre Farkılış̧ması

Araştırmamıza katılan öğrenci velilerinin ilköğretim okullanndaki din kültürü ve ahlak bilgisi öğretimi uygulamalanna karşı tutumlan ekonomik durum kategorilerine göre anlamlı bir şekilde farkllaş̧maktadır. Varyanslann eşitliği varsayımına göre yapılan LCD testi sonuçlanna göre bu farkllaşmanın kaynağında orta gelir grubunda bulunan velilerin $\mathrm{DKAB}$ dersi uygulamalanna karşı olan tutum düzeyleri ile çok düşük, düşük ve yüksek gelir grubunda bulunan velilerin tutum düzeyleri arasındaki farklllaşmadır. 
Orta düzey ekonomik güce sahip olan velilerin $\mathrm{DKAB}$ uygulamalanna karşı olan tutum puanlan diğer ekonomik gruplarda bulunanlara göre yüksektir. Yine LCD testi sonuçlan yüksek gelir grubu ile çok yüksek gelir grubu arasında da tutum düzeyleri arasında anlamlı bir farklllaşma belirlemiștir. Çok yüksek ekonomik grup içinde bulunan öğrenci velilerinin tutum düzeyleri yüksek ekonomik seviyede bulunan velilere göre yüksek görünmektedir.

Tablo 21 . Velilerin ilköğretim Din Kültürü ve Ahlak Bilgisi Öğretimi Uygulamalarına Karşı Tutumlarının Ekonomik Durumlarına Göre Farklılaşması (Anova)

\begin{tabular}{l|l|c|c|c}
\hline & Gelir Seviyesi & N & Mean & S \\
\hline 1 & Cok Yüksek & 27 & 3,5031 & 0,77339 \\
\hline 2 & Yüksek & 20 & 3,0333 & 0,65351 \\
\hline 3 & Ora & 13 & 3,7436 & 0,65080 \\
\hline 4 & Düsük & 26 & 3,1763 & 0,78610 \\
\hline 5 & Sok Düsük & 16 & 3,0573 & 0,85240 \\
\hline & TOPLAM & 102 & 3,2884 &, 77339 \\
\hline
\end{tabular}

\begin{tabular}{l|c|c|c|c|c}
\hline & Sum of Squares & Df & Mean Square & F & Sig. \\
\hline Between Groups & 6,421 & 4 & 1,605 & 2,884 &, 026 \\
\hline Within Groups & 53,992 & 97 &, 557 & & \\
\hline Total & 60,412 & 101 & & & \\
\hline Multiple Comparisons & & & & \\
\hline
\end{tabular}

Dependent Variable: DKAB Tutum Ortalamas1

LSD

\begin{tabular}{|c|c|c|c|c|}
\hline & & Mean Difference $(1-\sqrt{ })$ & Std. Error & Sig. \\
\hline (I) GELIR (REOODE) & (J) GELIR (RECODE) & & & \\
\hline \multirow[t]{4}{*}{ Sok Düşük Gelir Grubu } & Düşük gelir grubu &,- 1190 &, 2371 & ,617 \\
\hline & Orta gelir grubu &,$- 6863 \bullet$ & ,2786 &, 016 \\
\hline & Yüksek gelir grubu & $2,396 \mathrm{E}-02$ & ,2502 &, 924 \\
\hline & Cok yüksek gelir grubu &,- 4458 & 2354 &, 061 \\
\hline \multirow[t]{4}{*}{ Düşük Gelir Grubu } & Çok dü̧̧ük gelir grubu &, 1190 & ,2371 & 617 \\
\hline & Orta gelir grubu &,$- 5673 \bullet$ & ,2534 & ,027 \\
\hline & Yüksek ge lir grubu &, 1429 &, 2219 &, 521 \\
\hline & Cok yüksek gelir grubu &,- 3268 & ,2050 & 114 \\
\hline \multirow[t]{4}{*}{ Orta Gelir Grubu } & Sok düşük gelir grubu & ,6863• & 2786 & ,016 \\
\hline & Düşük gelir grubu &, $5673 \bullet$ & 2534 &, 027 \\
\hline & Yüksek gelir grubu & 7103 & 2658 &, 009 \\
\hline & Sok yüksek gelir grubu &, 2405 & .2519 &, 342 \\
\hline \multirow[t]{4}{*}{ Yüksek Gelir Grubu } & Çok düşük gelir grubu & $-2,3958 \mathrm{E}-02$ &, 2502 &, 924 \\
\hline & Düşük gelir grubu &,- 1429 &, 2219 &, 521 \\
\hline & Orta gelir grubu &., $7103 \bullet$ & ,2658 & ,009 \\
\hline & Çok yüksek gelir grubu &,$- 4698 \bullet$ & 2201 & 035 \\
\hline
\end{tabular}




\begin{tabular}{c|l|c|c|c}
\hline & & Mean Difference (I-J) & Std. Error & Sig. \\
\hline \multirow{2}{*}{ Sok Yüksek Gelir Grubu } & Çok düşük gelir grubu &, 4458 &, 2354 &, 061 \\
\hline & Düşük gelir grubu &, 3268 &, 2050 &, 114 \\
& Ora gelir grubu &,- 2405 &, 2519 &, 342 \\
& Yüksek gelir grubu &, $4698 \bullet$ &, 2201 &, 035 \\
\hline
\end{tabular}

* The mean difference is significant at the .05 level.

Tablo 21'deki veriler birlikte incelendiği zaman DKAB tutum ortalamalannun gelir gruplanna göre anlamlı bir şekilde farklulaştı̆ğ gözlenmektedir. $\mathrm{Bu}$ farkın kaynağın belirlemek amacıyla yapılan LCD testi sonuçlanına göre orta gelir grubunda bulunan öğrenci velilerinin çok düşük, düşük ve yüksek gelir grubunda bulunan velilere göre yüksek $D K A B$ tutum ortalamasına sahip olduğu belirlenmiştir. Ayn şekilde yüksek gelir grubunda bulunan öğrenci velileri, çok yüksek gelir grubunda bulunan velilere göre daha yüksek DKAB tutum ortalamasına sahiptir. Elde ettiğimiz bu bulgular, öğrenci velilerinin gelir seviyelerinin uç noktalarda bulunmasının $D K A B$ derslerine karşı olumsuz bir tutum sergilemelerine sebep olduğu sonucuna götürmektedir.

\section{F. Sonuç ve Değerlendirme}

Ankara ilindeki ilköğretim okullarının 6,7 ve 8. sunıflarında okumakta olan çocuğu olan 102 öğrenci velisi üzerinde "Velilerin Illköğretim Din Kültürü ve Ahlak Bilgisi Dersine Tutumlan" isimli ölçek geliştirme amacıyla yapmış olduğumuz bu araştırmada şu sonuçlara ulaşılmuştır:

1. Velilerin ilköğretim din kültürü ve ahlak bilgisi derslerine tutumlann ölçmek amacıyla geliştirdiğimiz ölçek, yapılan faktör analizi sonucunda bu amacı ölçebilecek iki ayn faktör ortaya çkarmıştır. Her bir alt boyutun geçerlik ve güvenilirlik katsaylan yüksektir. Bu faktörlerin birincisi "Velilerin Ilköğretim Din Kültürü ve Ahlak Bilgisi Uygulamalanna Tutumlan" ikincisi ise "Din Öğretimine Karşı Genel Tutum" olarak isimlendirilmiştir.

2. Dini tutumlann ölçülmesi amacıyla oluşturulan ölçeğin faktör analizi sonucunda anlamlı alt boyutlar oluşmadığından teorik yaklaşımlara dayanularak tek faktörlü iki ayn ölçek belirlenmiş, bunlardan birincisiyle velilerin dini inanç tutumlan, ikincisi ile de velilerin geleneksel-ilmihalci tutum düzeyleri ölçülmüsstür. Her iki ölçeğin de geçerlik ve güvenilirlikleri yüksek düzeyde çıkmıştır.

3. Oluşturulan dört ölçeğin birbirleri ilişkileri korelasyon testine tabi tutulmuş, din öğretimine tutum puanlanının dini inanç ve geleneksel-ilmihalci anlayıs tutumlanyla ilişkili olduğu belirlenmiştir. Illköğretim Din Kültürü ve Ahlak Bilgisi uygulamalanna tutum ile dini inanç ve geleneksel ilmihalci anlayş tutumlan arasında ise anlamh bir ilişki belirlenmemiştir. 
4. Din öğretimine karşı genel tutumlar ile dini inanç ve gelenekselilmihalci anlayşs tutumları arasında yaplan Regresyon analizi sonucunda dinin inanç ve geleneksel-ilmihalci anlayıs tutum düzeylerindeki artı̧ın, din öğretimine karşı genel tutum düzeylerinde artışa neden olduğu ve bu iki faktörün din öğretimine karşı tutumlarn yaklaşı \%31'ini açıkladığı sonucuna ulaşılmıstur.

5. Velilerin cinsiyet, eğitim durumu ve mesleklerinin bağımsız değişkenler olarak dini inanç, geleneksel ilmihalci anlayış, din öğretimine genel yaklaşım ve ilköğretim $D K A B$ dersleri uygulamalanna karşı tutumlarda istatistiksel açıdan anlamlı farklllaşmalar oluşturmadığı yapılan analizler sonucunda ortaya çikmıştur.

6. Yaptğımız araştırma, öğrenci velilerinin din öğretimi ve ilköğretim DKAB öğretimine ilişkin tutumlanının açıklamasında dini tutum ve geleneksel din anlayışı tutumlannın belirleyici olduğunu göstermiştir. Ancak, burada açıklanamayan yaklaşık \%70 gibi önemli bir boşluk bulunmaktadır. Bu aşamadan sonra yaplacak araştırmalarda, velilerin Din öğretimine karşı tutumlannı etkilediği varsaylan farklı noktalara eğilinmesi ve bu noktalan belirlemek amacıyla geliş̧irilen ölçme araçlanyla daha geniş bir alanun açıklanmasına yönelik çalışmalann yapılması gerekmektedir. 